\title{
Application of Erodibility Nomograph in the Assessment of Soil Erosion in Two Different Agro-ecological Zones
}

\author{
ENYA AKPA ${ }^{1}$, PAUL OKON-INYANG ${ }^{1}$, MICHAEL OTU $^{1}$, SUNDAY AFU ${ }^{1}$, and OLIM \\ MICHAEL $^{1}$
}

${ }^{1}$ University of Calabar Faculty of Agriculture

August 28, 2020

\begin{abstract}
This study highlights application of erodibility nomograph to assess soil erosion in central and northern agro-ecological zones of Cross River State, Nigeria. Seventeen composite soil samples were collected from sites showing moderate to severe erosion problems to the depth of $0-30 \mathrm{~cm}$ with the use of soil auger by random sampling and analyzed using standard laboratory procedures. Results showed that the particle size analysis was coarse textured soils with high sand content giving dominant textural classes of sandy loam in central and loamy sand texture in northern agro-ecological zones. The soil separates were predominantly silt content in central and medium sand in the northern agro-ecological zones with mean values of $29.5 \%$ and $26.3 \%$. The erodibility using nomograph showed low to medium $(0.10-0.19 \mathrm{Mg}$ ha- $1 \mathrm{MJ} \mathrm{mm}-1)$ in the central and medium (0.20 - $0.29 \mathrm{Mg}$ ha-1 MJ mm-1) in the northern agro-ecological zones with high CV (\%) of $52.4 \%$ in the central and $118.2 \%$ in the northern agro-ecological zones suggesting erodible soils. Soil conservation measures such as contouring, mulching and cover cropping should be adopted to address and combat soil erosion to avoid serious soil erodibility.
\end{abstract}

\begin{abstract}
This study highlights application of erodibility nomograph to assess soil erosion in central and northern agro-ecological zones of Cross River State, Nigeria. Seventeen composite soil samples were collected from sites showing moderate to severe erosion problems to the depth of 0-30 $\mathrm{cm}$ with the use of soil auger by random sampling and analyzed using standard laboratory procedures. Results showed that the particle size analysis was coarse textured soils with high sand content giving dominant textural classes of sandy loam in central and loamy sand texture in northern agro-ecological zones. The soil separates were predominantly silt content in central and medium sand in the northern agro-ecological zones with mean values of $29.5 \%$ and $26.3 \%$. The erodibility using nomograph showed low to medium $\left(0.10-0.19 \mathrm{Mg} \mathrm{ha}^{-1} \mathrm{MJ} \mathrm{mm}^{-1}\right)$ in the central and medium $\left(0.20-0.29 \mathrm{Mg} \mathrm{ha}^{-1} \mathrm{MJ} \mathrm{mm}^{-1}\right)$ in the northern agro-ecological zones with high CV (\%) of $52.4 \%$ in the central and $118.2 \%$ in the northern agro-ecological zones suggesting erodible soils. Soil conservation measures such as contouring, mulching and cover cropping should be adopted to address and combat soil erosion to avoid serious soil erodibility.
\end{abstract}

Key words: Soil erosion-erodibility-nomograph-assessment-agro ecological zones

\section{INTRODUCTION}

Soil erosion appears to be the greatest factor limiting soil productivity and impeding agricultural enterprise in the entire humid tropical region (Lal et al., 2003) and constitutes one of the main environmental problem that cause soil erodibility in central and northern agro-ecological zones of Cross River State, Nigeria. The soils are structurally fragile, loose, highly weathered, leached, acidic and very susceptible to different forms of water erosion including catastrophic erosion due to heavy rainfall and and human activities (Chikezie et al., 2010). The soils are strongly acidic with $\mathrm{pH}$ value ranging from 4.1 to 5.5 (Ibia et al., 2011). The soils 
are characterized by weak, fine crumb surface horizons and weak sub-angular subsurface horizons (Esu et al ., 2008).

Erodibility or erodability denoted by $\mathrm{K}$ reflects the susceptibility of soil to erosion and is an inherent soil characteristic which cannot be readily controlled. The main soil properties affected by soil erodibility to erosion are soil texture, including the amount of fine sand in addition to the usual sand, silt, and clay, organic matter, structure, and permeability of the soil profile. Wischmeier and Smith (1978) stated that the unit plot, which is defined as the standard plot condition is used to determine the soil's erodibility on a condition where the LS factor $=1$ (slope $=9 \%$ and length $=22.13 \mathrm{~m}$ ) and the plot is fallow and tillage is up and down slope and no conservation practices are applied $(\mathrm{CP}=1)$. The $\mathrm{K}$ factor is influenced by the detachability of the soil, infiltration and runoff, and the transportability of the sediment eroded from the soil (Brady and Weil, 2008).

Clay soils have a low K value and resistant to detachment. Sandy soils have low K values and high infiltration rates, reduced runoff, and sediment eroded from these soils is not easily transported. The soil erodibility potential is low for high clayey soil and coarse to medium grained granular soils. Silt loam soils have moderate to high $\mathrm{K}$ values and easily detached, infiltration is moderate to low producing moderate to high runoff, and the sediment is moderate and easily transported. Silt soils have the highest K values and readily crust producing high runoff rates and amounts. The soil erodibility can be high to medium for low to non-plastic soil and soil with significant amount of silt and fine sand.

Wischmeier et al. (1971) developed the first analytical method to estimate soil erodibility which is a graphical representation (nomograph) based on an indirect combination of physical properties and percentage of organic matter. The soil erodibility nomograph provides a graphical solution for determining a soil's $\mathrm{K}$ value, and can be used if the percent sand and organic matter fractions in a particular soil are known. Vanelslande et al., 1984; Obi et al., 1989 concluded that the nomograph was developed with soils having substantial fine particles. According to Renard et al., 1997; Morgan, 2005, the nomograph is adequate for surface soils, less aggregated soils and medium textured soils, not used for soils with high organic matter (more than 4\%), swelling clays and soils in which aggregate stability is more influential than primary particle size. Wischmeier et al. (1971) stated that the factors considered in the K factor estimation in the nomograph (Fig. 1) consist of soil particles (\% sand, $\%$ silt, $\%$ very fine sand and silt, and \% clay), $\%$ organic matter, soil structure code and soil permeability class.

Erodibility can also be expressed in mathematical terms for calculation of the $\mathrm{K}$ factor instead of reading the nomograph. According to Wischmeier et al. (1971), the mathematical expression takes the form:

Blanco and Lal (2008) modified the mathematical expression where all the soil parameters found in the above equation have the same definition. The modified equation takes the form:

$0.00021 \times M^{1.14} \times(12-a)+3.25 \times(b-2)+3.3 \times 10^{-3}(c-3)$

100 Eqn. (2)

Where; $M$ is the particle size parameter, given by $M=(\%$ silt $+\%$ very fine sand $) \times(100-\%$ clay $)$

$\mathrm{a}=\%$ of organic matter content, $\mathrm{b}=$ soil structure class $(1=$ very fine granular; $2=$ fine granular; $3=$ medium or coarse granular; $4=$ blocky, platy, or massive), $\mathrm{c}=$ soil profile permeability (saturated hydraulic conductivity) class $[1=\operatorname{rapid}(150 \mathrm{~mm} / \mathrm{h}) ; 2=$ moderate to rapid $(50-150 \mathrm{~mm} / \mathrm{h}) ; 3=$ moderate $(12-50$ $\mathrm{mm} / \mathrm{h}) ; 4=$ slow to moderate $(5-15 \mathrm{~mm} / \mathrm{h}) ; 5=$ slow $(1-5 \mathrm{~mm} / \mathrm{h}) ; 6=$ very slow $(<1 \mathrm{~mm} / \mathrm{h})]$.

In West Africa, arbitrary relative grades of erosion risk observed by Landon (1991) for soil erodibility values were $0.09 \mathrm{t} \mathrm{ha}^{-1} \mathrm{MJmm}^{-1}$ (low), 0.10-0.19 $\mathrm{t} \mathrm{ha}^{-1} \mathrm{MJmm}^{-1}$ (low to medium), 0.20-0.29 $\mathrm{t} \mathrm{ha}^{-1} \mathrm{MJmm}^{-1}$ (medium), 0.30-0.39 $\mathrm{t} \mathrm{ha}^{-1} \mathrm{MJmm}^{-1}$ (medium to high), 0.40-0.59 $\mathrm{t} \mathrm{ha}^{-1} \mathrm{MJmm}^{-1}$ (High) and $0.60 \mathrm{t} \mathrm{ha}^{-1} \mathrm{MJmm}^{-1}$ or more (very high). Manrigue (1988) reported the following tropical values: $\mathrm{K}=0.18$ for Hawaii; $\mathrm{K}=0.20$ for Island of Mali and $\mathrm{K}=0.31$ for Panama soils. Vanelslande et al., 1984; Obi et al., 1989 compared soil erodibility values from runoff plots in Southern Nigeria using nomograph and mathematical term for evaluation 
in the Universal Soil Loss Equation and showed significant existed between the two methods which shows inadequacies in the nomograph due to dominance of medium to coarse sand in the tropical soils. However, Obi et al.(1989) found that actual measurement of soil erodibility was $0.007 \mathrm{t} \mathrm{ha}^{-1} \mathrm{MJmm}^{-1}$ by calculation compared with $0.012 \mathrm{t} \mathrm{ha}^{-1} \mathrm{MJmm}^{-1}$ using the nomograph. Conversely, estimation of erodibility using the nomograph have been useful and satisfactory under the condition it was developed.

The study therefore applies erodibility nomograph in the assessment of erosion in two different agro-ecological zones.

\section{MATERIALS AND METHODS}

\section{THE STUDY AREA}

The research was carried out in central and northern agro-ecological zones of Cross River State., Nigeria. The central agro-ecological zone lies between Latitude $05^{0} 58^{\prime} \mathrm{N}$ and Longitude $08^{0} 04^{\prime} \mathrm{E}$ and the areas studied include Yakurr (Latitude $05^{\circ} 48^{\prime} 05.9^{\prime \prime} \mathrm{N}$ and Longitude $08^{\circ} 05^{\prime} 36.2^{\prime \prime} \mathrm{E}$ ), Abi (Latitude $05^{0} 53^{\prime} 12.0^{\prime \prime} \mathrm{N}$ and Longitude $08^{0} 01^{\prime} 58.3^{\prime \prime} \mathrm{E}$ ) and Ikom (Latitude $06^{0} 03^{\prime} 40.8^{\prime \prime} \mathrm{N}$ and Longitude $\left.08^{0} 40^{\prime} 01.9^{\prime \prime} \mathrm{E}\right)$. While the northern agro-ecological zone lies between Latitude $06^{0} 43^{\prime} \mathrm{N}$ and Longitude $09^{0} 10^{\prime} \mathrm{E}$ (BulkTrade, 1989) and the areas studied include Ogoja (Latitude $06^{\circ} 39^{\prime} 31.8^{\prime \prime} \mathrm{N}$ and Longitude $08^{0} 48^{\prime} 27.9^{\prime \prime} \mathrm{E}$ ), Yala (Latitude $06^{0} 42^{\prime} 53.4^{\prime \prime} \mathrm{N}$ and Longitude $08^{\circ} 46^{\prime} 45.9^{\prime \prime} \mathrm{E}$ ) and Obudu (Latitude $06^{0} 40^{\prime} 10.4 " \mathrm{~N}$ and Longitude $09^{0}$ 09' 44.4" E) in the northern agro-ecological zone of Cross River State Cross River State. A Garmin Global positioning system 12 was used to geo-reference the area of the sampling location.

The climate is mostly tropical-humid which lies in the tropical rainforest climatic zone with dry and wet seasons except on the Obudu plateau (500 feet above sea level) in the agro-ecological zone of northern Cross River State where due to altitude, it is temperate throughout the year. Average temperature ranges between $15^{0} \mathrm{C}$ and $23^{\circ} \mathrm{C}$. The annual rainfall is $4300 \mathrm{~mm}$. The average sunshine hours ranges between 4.1 and 4.9 hours with mean of 4.5 hours (Nwajiuba and Onyeneke, 2010).

The underlying geological materials within the central agro-ecological zone consist of sandstone-shale intercalation in Yakurr and Abi, basalt (Basaltic lava) in Ikom. While those of the northern agro-ecological zone consist of sandstone in Ogoja and Yala, basement complex (granite, gneiss, quartzite and schist) in Obudu. The soils are commonly acidic in nature due to intensive rainfall in the areas. The soils are well drained, deep laterite fertile, sandy, clay, basalt and heavily leached. The areas are characterized by gently and steeply sloping landscape of 0-9\% overall without shoulder but the crest gradually sloping towards the valley bottom with moderate to high erosion conditions (Ibanga, 2006; Esu et al ., 2008; Ekwueme, 2003).

The natural vegetation of the areas are characterized by tropical rainforest, guinea savanna and derived savanna. In the central agro-ecological zone, the vegetation is predominantly tropical rainforest ecosystem with heavy upland forest, Fresh water swamps and Mangrove swamps. While in the northern agro-ecological zone, the vegetation is is characterized by grassland, mangrove, forest with pocket of immature and mature forest of the derived savanna zone and Parkland vegetation. The increase in rainfall amount and frequency lead to soil erodibility caused by erosion. Common plant species in the areas include guinea grass (Panicum maximum), elephant grass (Pennisetum purpureum ), teak (Tectona gradis), Gmelina(Gmelina arborea), pear (Dacryadis edulis) and timber trees. The major crops in the areas include rice (Oryza sativa) oil palm (Elaeis guinensis), cocoa (Theobroma cacao),cassava (Manihot spp.), plantain (Musa paradisiaca), yam(Dioscorea spp.), pineapple (Ananas comosus) and so on (BulkTrade, 1989; Effiong, 2011).

\section{SITE SELECTION/FIELD WORK}

Photogrammetric survey of the areas was carried out by aerial photograph to select major areas prone to erosion problems. Seventeen (17) composite soil samples were collected from sites showing moderate to severe erosion problems to the depth of 0-30 $\mathrm{cm}$ with the use of soil auger by random sampling in the study areas. The seventeen (17) composite samples were bagged, labeled and transported to the University of Calabar Soil Science Laboratory for analysis. 


\section{LABORATORY ANALYSES}

The soil structure was carried out under field condition by visual soil evaluation (VSE) techniques as outlined by Emmet-Booth et al.(2018). The soil profile permeability was obtained from saturated hydraulic conductivity (SHC) class (Blanco and Lal, 2008). Particle size analysis for determination of texture was analyzed by Bouyoucous hydrometer method using sodium hexametaphosphate (VII) (Calgon) as the dispersant (Udo et al., 2009). Soil texture was determined using USDA soil textural triangle (SSS, 1999). Bulk density was determined using the core method as described by Blake and Hartge (1986). Particle density was determined by the pycnometer method following the procedures outlined by Bowles (1992). Soil separate was determined by washing the soil sample with calgon and water to allow the clay, silt and sand separates as described by Bouyoucos (1951) hydrometer method. The sand content was removed, dried and passed through set of sieves to obtain sand separates. Saturated hydraulic conductivity $\left(\mathrm{K}_{\text {sat }}\right)$ was obtained by the method outlined by Saxton et al. (1986). Organic Carbon was determined by the Walkley and Black method as outlined by Nelson and Sommers (1996). Erodibility, K was estimated by USLE nomograph from soil analysis of proportion of silt + very fine sand, amount of organic matter, structural class and permeability class as outlined by Wischmeieret al. (1971).

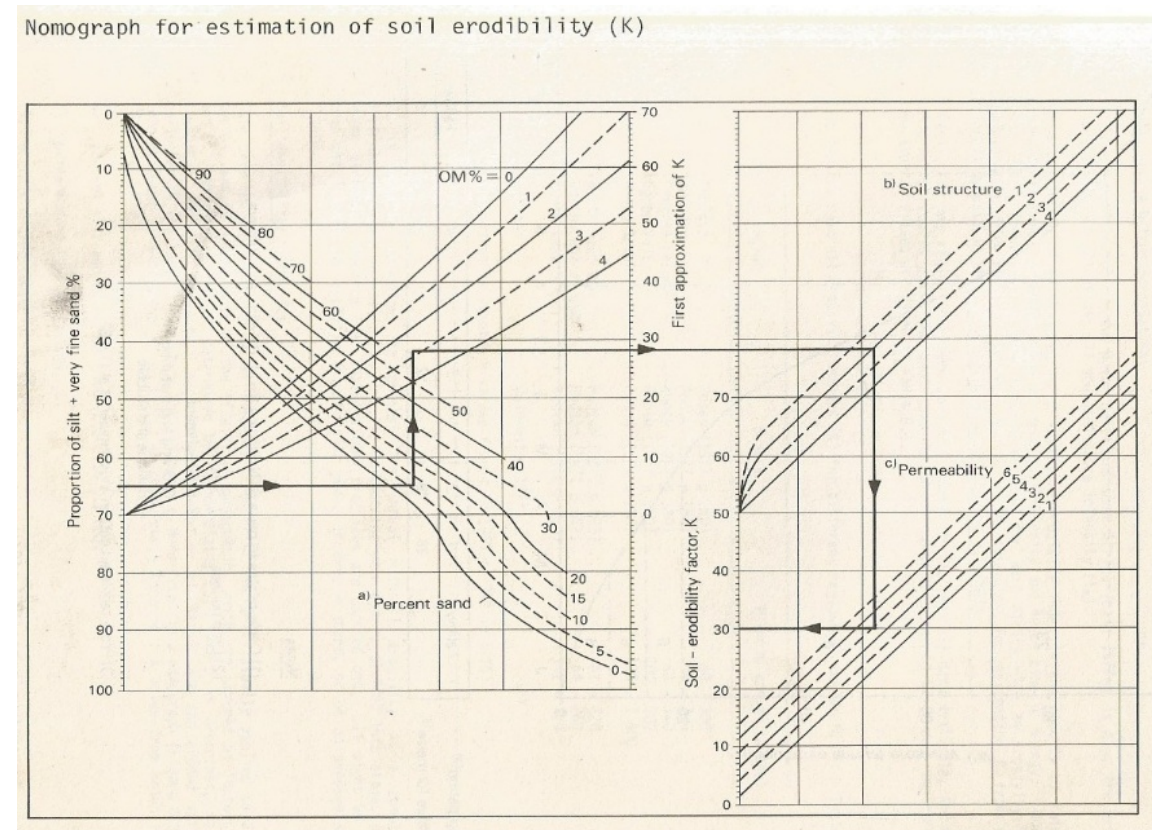

\section{DATA STATEMENT/ ANALYSIS}

There was no data available for this study. All the data were obtained from analysis and the results were subjected to coefficient of variation and simple descriptive statistics of mean and range.

\section{RESULTS AND DISCUSSIONS}

\section{PHYSICAL PROPERTIES}

The physical properties of soils in the central and northern Agro-ecological zones, Cross River State are presented in Table 1. The soils had high sand with low silt and clay contents giving dominant textural classes of sandy loam in the central zone and loamy sand in the northern zone. The high sand and low silt contents suggests how the soils are well drained and easily transported by water while the low clay content signifies low holding water capacity. Blanco and Lal (2008) reported that the most erodible type of soils is silt followed by sand and clay. The soil separates were predominantly silt in the central agro-ecological zone 
and medium sand in the northern agro-ecological zone. Silt particles are low in water holding capacities hence provide excellent drainage characteristics and easily detached of the soils because they are small and do not easily form aggregates. Medium sand are high in water movement, hence facilitate percolation and easily transportation of water which detach the soils more easily. The saturated hydraulic conductivity was generally moderate to rapid with mean values ranging from $50-150 \mathrm{~mm} / \mathrm{hr}$. in the two agro-ecological zones. This showed high water movement when the soil is saturated with water which might be attributed to the high sand content. Park and Smucker (2005) observed that high movement of water in soils result to condition of moderate to rapid saturated hydraulic conductivity due to their macroaggregate condition. The bulk densities were generally low in the two agro-ecological zones. Less than $1.4 \mathrm{~g} \mathrm{~cm}^{-3}$ generally indicates porous soil condition which leads to soil erosion. Hunt and Gilkes, 1992; McKenzie et al., 2004 reported that the critical values of bulk density for encouraging erosion and restricting root growth varies with soil type but bulk densities less than $1.8 \mathrm{~g} \mathrm{~cm}^{-3}$ encourage soil erosion and greater than $1.8 \mathrm{~g} \mathrm{~cm}^{-3}$ generally tend to restrict root growth. The particle densities of the soil obtained for this study were all lower than the value of $2.65 \mathrm{~g} \mathrm{~cm}^{-3}$ recommended for tropical soils in the two agro-ecological zones as reported by Stutter et al. (2004) except for Obudu in the northern agro-ecological zone, where their mean values were above $2.65 \mathrm{~g}$ $\mathrm{cm}^{-3}$. The difference in their means were quite minimal and less than the average of $2.6 \mathrm{~g} \mathrm{~cm}^{-3}$ obtained by Chopra.and Kanwar (1991). The resulting CV of all the physical properties was high in both central and northern agro-ecological zones but decrease rapidly toward the northern zone, suggesting a relatively high variability.

Table 1: Soil physical properties in the central and northern agro-ecological zones, Cross River State

\begin{tabular}{|c|c|c|c|c|c|c|c|c|c|c|}
\hline Location & SAMPLING POINT & DEPTH & & PSA (\%) & & $\mathrm{TC}$ & $\mathrm{SHC}$ & $\mathrm{BD}$ & $\mathrm{PD}$ & CLAY \\
\hline Central & & $(\mathrm{cm})$ & SAND & SILT & CLAY & & (mm/hr.) & $\mathrm{gcm}^{-1}$ & $\mathrm{gcm}^{-1}$ & \\
\hline \multirow[t]{6}{*}{ Ugep } & Katabebe. Upp.Sl. & $0-30$ & 58 & 37 & 5 & SL & 58.56 & 1.53 & 2.5 & 5 \\
\hline & Katabebe. Midd.Sl. & $0-30$ & 55 & 44 & 1 & SL & 73.73 & 1.53 & 2.39 & 0 \\
\hline & Katabebe. L.Slope & $0-30$ & 65 & 34 & 1 & SL & 96.09 & 1.46 & 2.35 & 0 \\
\hline & Katabebe.V.Bottom & $0-30$ & 62 & 36 & 2 & SL & 101.42 & 1.35 & 2.61 & 2 \\
\hline & Obioko, Ijiman & $0-30$ & 81 & 17 & 2 & $\mathrm{LS}$ & 127.68 & 1.42 & 2.25 & 2 \\
\hline & Kekomkolo, Ijiman & $0-30$ & 81 & 17 & 2 & LS & 127.68 & 1.42 & 2.51 & 2 \\
\hline \multirow[t]{3}{*}{ Abi } & Anong, Bahumono & $0-30$ & 77 & 22 & 1 & LS & 118.46 & 1.45 & 2.54 & 0 \\
\hline & Itigidi Bridge & $0-30$ & 74 & 25 & 1 & LS & 111.56 & 1.52 & 2.57 & 0 \\
\hline & Inebor, Itigidi & $0-30$ & 78 & 21 & 1 & LS & 119.93 & 1.48 & 2.36 & 0 \\
\hline Ikom & Njang Assam & $0-30$ & 53 & 40 & 7 & SL & 96.16 & 1.35 & 2.18 & 0 \\
\hline Min & & & 53 & 17 & 1 & & 58.56 & 1.35 & 2.18 & 0 \\
\hline $\operatorname{Max}$ & & & 81 & 44 & 7 & & 127.68 & 1.53 & 2.61 & 5 \\
\hline Mean & & & 68.4 & 29.3 & 2.3 & & 103.127 & 1.451 & 2.426 & 1.1 \\
\hline CV (\%) & & & 16.1 & 34.1 & 89.6 & & 22.3 & 4.62 & 5.85 & 151 \\
\hline \multicolumn{11}{|l|}{ Northern } \\
\hline \multirow[t]{4}{*}{ Ogoja } & Ishibori & $0-30$ & 75 & 21 & 4 & LS & 94.17 & 1.47 & 2.43 & 9 \\
\hline & Isbibori valley b. & $0-30$ & 81 & 14 & 5 & $\mathrm{LS}$ & 95.49 & 1.46 & 2.45 & 5 \\
\hline & Agiga-Igoli & $0-30$ & 79 & 19 & 2 & LS & 122.12 & 1.48 & 2.25 & 2 \\
\hline & Stadium Road & $0-30$ & 73 & 26 & 1 & LS & 109.24 & 1.51 & 2.55 & 0 \\
\hline Yala & Okuku & $0-30$ & 78 & 17 & 5 & LS & 86.44 & 1.53 & 2.2 & 5 \\
\hline \multirow[t]{2}{*}{ Obudu } & Abonkep & $0-30$ & 69 & 30 & 1 & SL & 102.85 & 1.46 & 2.79 & 0 \\
\hline & Abonkep midd slope & $0-30$ & 71 & 26 & 3 & SL & 100.79 & 1.42 & 2.58 & 3 \\
\hline Min & & & 69 & 14 & 1 & & 86.44 & 1.42 & 2.2 & 0 \\
\hline $\operatorname{Max}$ & & & 81 & 30 & 5 & & 122.12 & 1.53 & 2.79 & 9 \\
\hline Mean & & & 75.14 & 21.9 & 3 & & 101.586 & 1.476 & 2.4643 & 3.43 \\
\hline CV (\%) & & & 5.87 & 26 & 57.7 & & 11.4 & 2.44 & 8.2 & 93.6 \\
\hline
\end{tabular}




\section{ESTIMATION OF ERODIBILITY USING NOMOGRAPH}

The estimation of erodibility using nomograph were from proportion of silt plus very fine sand, percent sand, percent organic matter, soil structure and permeability. These are presented in Table 2. The soil structure under field condition was dominated by very fine and fine granular structures belonging to classes 1 and 2 in the both agro-ecological zones. This indicates poor soil structures which might be attributed to the architectural arrangement of the soil particles and their aggregates of different size, shape and stability by detaching power of rain. Blanco and Lal (2008) reported that fine granular structure are more detachable, unstable and susceptible to compaction resulting to low water infiltration and high runoff rates. The soil profile permability was in class 2 according to the range of saturated hydraulic conductivity values obtained in the both agro- ecological zones and this indicates high movement of water and could detach soil particles. The OM was generally medium in both agro-ecological zones according to the rating of FDALR. (1990) and Landon (1991). The medium OM may be probably due to low accumulation of litter from leaf falls or residues that provide few cover to the soil to promotes erosion. Blanco-Canqui et al. (2006) reported low to medium organic matter contents and this could lead to soil erosion because the soil is bare and exposed to raindrop impact. The CV (\%) of the OM was high with 35.5 and $50.3 \%$ in the central and northern agro-ecological zones, all suggesting low accumulation and this could lead to soil erodibility. The proportion of silt plus very fine sand was high with mean values of 31.9 and $22.7 \%$ in both zones. The CV (\%) was high with 31.1 and $27.5 \%$ in both zones suggesting easily detach of soils by erosion. The percent sand was high with mean values of 69.2 and $75.1 \%$ in both zones. The resulting CV (\%) was high with 14 and $5.87 \%$ in both zones suggesting porous condition of the soil. The erodibility, $\mathrm{K}$ values were low to medium $\left(0.10-0.19 \mathrm{Mg} \mathrm{ha}^{-1} \mathrm{MJ} \mathrm{mm}{ }^{-1}\right)$ in the central and medium $\left(0.20-0.29 \mathrm{Mg} \mathrm{ha}^{-1} \mathrm{MJ} \mathrm{mm}^{-1}\right)$ in the northern agro-ecological zones. The values obtained conform with the similar values reported by Landon (1991). The erodibility values indicate less soil erodibilities which might be attributed to the high contents of silts and very fine sand. The CV (\%) was high with $52.4 \%$ in the central and $118.2 \%$ in the northern agro-ecological zones indicating a relatively high variation.

Table 2: Soil parameters used for estimation of erodibility, $\mathrm{K}$ and values obtained in central and northern agro-ecological zones

\begin{tabular}{|c|c|c|c|c|c|c|c|}
\hline Location & Sampling points & Depth & Structure & Organic & Pr. of silt + VFS & Proportion & Permeability \\
\hline & & $(\mathrm{cm})$ & Class & Matter (\%) & $(\%)$ & of sand & Class \\
\hline \\
\hline \multirow[t]{7}{*}{ Yakuur } & Katebebe,Ugep & $0-30$ & 2 & 1.97 & 28.1 & 71 & 2 \\
\hline & Katabebe. Upp.Slope & $0-30$ & 2 & 1.31 & 45.9 & 58 & 2 \\
\hline & Katabebe. Midd.Slope & $0-30$ & 4 & 1.31 & 45.49 & 55 & 2 \\
\hline & Katabebe. L.Slope & $0-30$ & 3 & 2.03 & 36.27 & 65 & 2 \\
\hline & Katabebe.V.Bottom & $0-30$ & 3 & 3.26 & 38.86 & 62 & 2 \\
\hline & Obioko, Ijiman & $0-30$ & 2 & 2.34 & 19.62 & 81 & 2 \\
\hline & Kekomkolo, Ijiman & $0-30$ & 2 & 2.31 & 20.84 & 81 & 2 \\
\hline \multirow[t]{3}{*}{ Abi } & Anong, Bahomono & $0-30$ & 1 & 1.88 & 24.24 & 77 & 2 \\
\hline & Itigidi bridge & $0-30$ & 2 & 1.14 & 26.99 & 74 & 2 \\
\hline & Inebor, Itigidi & $0-30$ & 2 & 1.53 & 23.25 & 78 & 2 \\
\hline Ikom & Njang Assam, Dap.H. & $0-30$ & 3 & 3.19 & 41.44 & 59 & 2 \\
\hline Minimum & & & & 1.14 & 19.62 & 55 & \\
\hline Maximum & & & & 3.26 & 45.9 & 81 & \\
\hline Mean & & & & 2.02 & 31.9 & 69.2 & \\
\hline S.D & & & & 0.717 & 9.92 & 9.71 & \\
\hline $\mathrm{CV}(\%)$ & & & & 35.5 & 31.1 & 14.0 & \\
\hline \multirow{3}{*}{$\begin{array}{l}\text { Northern } \\
\text { Ogoja }\end{array}$} & & & & & & & \\
\hline & Isbibori & $0-30$ & 1 & 1.86 & 17.64 & 75 & 2 \\
\hline & Ishibori, V. B. & $0-30$ & 1 & 2.03 & 15.89 & 81 & 2 \\
\hline
\end{tabular}




\begin{tabular}{|c|c|c|c|c|c|c|c|}
\hline Location & Sampling points & Depth & Structure & Organic & Pr. of silt + VFS & Proportion & Permeability \\
\hline & Agiga - Igoli & $0-30$ & 1 & 1.36 & 20.2 & 79 & 2 \\
\hline & Stadium Road & $0-30$ & 3 & 1.19 & 28.45 & 73 & 2 \\
\hline Yala & Okuku & $0-30$ & 1 & 0.1 & 18.22 & 78 & 2 \\
\hline \multirow[t]{2}{*}{ Obudu } & Abonkep & $0-30$ & 2 & 1.88 & 31.99 & 69 & 2 \\
\hline & Abonkep Middle slope & $0-30$ & 2 & 2.55 & 26.8 & 71 & 2 \\
\hline Minimum & & & & 0.1 & 15.89 & 69 & \\
\hline Maximum & & & & 2.55 & 31.99 & 81 & \\
\hline Mean & & & & 1.57 & 22.7 & 75.1 & \\
\hline S.D & & & & 0.79 & 6.25 & 4.41 & \\
\hline CV (\%) & & & & 50.3 & 27.5 & 5.87 & \\
\hline
\end{tabular}

$\mathrm{VFS}=$ very find sand; $\mathrm{CV}=$ coefficient of variation; $\mathrm{S} . \mathrm{D}=$ standard deviation; $\mathrm{V} . \mathrm{B}=$ valley bottom

\section{CONCLUSIONS}

From the research carried out in the studied areas, the soils were erodible, coarse textured, structurally fragile, loose, highly weathered, acidic and susceptible to different forms of erosion with erodibilities of low to medium in the central agro-ecological zone and medium in the northern agro-ecological zone. Their coefficient of variation was high in all the physical properties and erodibility which does not show a good fit. The erosion in the area had posed minor problems which could hinder the productivity of the soils for crop growth, hence soil conservation measures such as contouring, mulching and cover cropping should be carried out to address and combat soil erosion to avoid serious soil erodibility.

\section{ACKNOWLEDGEMENTS}

The authors thanked the staff and management of Department of Soil Science, University of Calabar for granting approval to use Departmental facilities for the research work, and Messer's Mark Onah and E. O. Ekpenyong for laboratory analysis of the soil samples. The research was not funded by any corporate body.

\section{CONFLICT OF INTEREST STATEMENT}

On behalf of all authors, the corresponding author states that there is no conflict of interest.

\section{REFERENCES}

Blake, G. R., and Hartge, K. H. (1986). Bulk density. In: Klute, A., Ed., Methods of Soil Analysis Part 1. Physical and Mineralogical methods. Am. Soc. of Agronomy- Soil Science Society of America, Madison, http://doi.org/10.2136/ssabookser5.1. 2ed.c13.

Blanco, H. and Lal, R. (2008). Principles of Soil Conservation and Management.Springer . ISBN 978-40208708-097. Pp 41-42

Blanco-Canqui, H., Lal, R., Winifred, M., Izaurraide, R. C. and Shipitalo, M. J. (2006). Organic Carbon influences on (9) DOI:10.2136/Sssaj2005.0355.

Bouyoucos, G. H. (1951). A re-calibration of the hydrometer for making mechanical analysis of soils. Agron. J., 43, 434-438. http://doi.org/10.2134/agronj1951.00021962004300090005x

Bowles, J. E. (1992). Engineering properties of soil and their measurements $4^{\text {th }}$ (ed.) Mcgraw Hills, Boston pp. 241

Brady, N. C. and Weil, R. O. (2008). Nature and properties of soil (14 ${ }^{\text {th }}$ ed.,). Pearson Publisher, ISBN 13:978-0132279383 Pp 90,108.

BulkTrade Investment Company Limited. (1989). Main report on Soil and Land use survey of Cross River State Ministry of Agriculture and Natural Resources, Calabar 
Chikezie, I. A., Eswaran, I. A., Asawalam, D. O. and Ano, A. O. (2010). Characterization of two benchmark soils of contrasting parent materials in Abia State, Southern Nigeria. Global Journal of Pure Applied Science , 16(1), DOI: 10.4314/ipas.v16i1.66190

Chopra, S. L.and Kanwar, J. S. (1991). Analytical Agricultural Chemistry (4th ed.). Kalyani Publishers. New Delhi, India, ISBN: 817096444x 9788170964445, 488pp.

Effiong, J. (2011). Changing pattern of land use in the Calabar river catchment, Southern Nigeria. Journal of sustainable development,41(1), DOI: 10.5539/jsd.v4n1p92

Ekwueme, B. N. (2003). The Precambrian Geology and Evolution of the Southeastern Nigeria basement complex. Calabar. University of Calabar press. Pp 45

Emmet-Booth, J. P., Forristal, P. D., Fenton, O., Bondi, G. and Holden, N. M. (2018). The influence of depth of observation on the information conveyed by visual soil evaluation. Soil and Tillage Research , http:/doi.or/10.1111/sum.12396

Esu, I. E., A. U. Akpan-Idiok and Eyong, M. O. (2008). Characterization and Classification of soils along a typical Hillslope in Afikpo area of Ebonyi State, Nigeria. Nigeria Journal of Soil and Environmental Research, DOI 10.4314/njser. v8i1.52050

FDALR. (1990). The reconnaissance soil survey of Nigeria (1:450,000) Soil report (Lagos, Ogun, Oyo, Ondo, Bendel States). Federal Department of Agricultural Land Resources, Lagos 1.

Hunt, N. and Gilkes, R. (1992). Farm Monitory Handbook. The University of Western Australia: Nedlands, WA.

Ibanga, I. J. (2006). Soil studies: the pedological approach, Calabar: MAESOT printing and computers. pp 66.

Ibia, T.O., Uko-Itakha, I. B., Edem, S.O., Ogban, P. I. and Obi, J. C.(2011). Evaluation of the Acid Soils for sanitary Landfills in Akwa-Ibom State, Southern Nigeria. Nigerian Journal of Soil Science. Vol 21(1):1-5

Lal, R., Den, B. C. and Wiebe, K. D. (2003). "Measuring on-site and off - site effects of erosion on productivity and environmental quality" in Proceeding of the OECD Expert meeting on Soil Erosion and Soil Biodiversity Indicators, Rome, Italy.

Landon, J. R. (1991). Booker Tropical Soil Manual. Longman Publishers, Harlow, UK., DOI: http://doi.org/10.4324/9781315846842

Manrigue, L. A. (1988). Land Erodibility Assessment Methodolog y. LEAM Using Soil Survey Data Based on Soil Taxonomy. Editorial and Publication Shop, Hawaii, 40 pp

McKenzie, N. J., Jacquier, D. J., Ishell, R. F. and Brown, K. L. (2004). Australian Soils and Landscapes. An illustrated Compendium. CSIRO Publishing Collingwood, Victoria.

Morgan, R. P. C. (2005). Soil erosion and conservation. $3^{\text {rd }}$ ed. Carlton: Blackwell Publishing, Oxford. https://doi.org/10.1111/j.1365-2389.2005.0756f.x

Nelson, D. W. and Sommers, L. E. (1996). Total Carbon, Organic Carbon and Organic. In O. L. Sparks (ed). Methods of Soil Analysis Part 3, Chemical Methods. Soil Science Society of America Book Series Number 5. American Society of Agronomy, Madison WIE, http://doi.org/10.2136/sssabookser5.3.c34

Nwajiuba, C. and Onyeneke, R. (2010). Effects of climate on the agriculture of sub-Saharan Africa: Lessons from Southeast Rainforest Zone of Nigeria. A paper presented at the Oxford Business and Economics Conference Program, UK.

Obi, M. E., Salako, F. K. and Lal, R. (1989). Relative susceptibility of some Southeastern Nigeria soils to erosion, Catena , (16), https://doi.org/ 10.1016/034-8162(89)90009-x 
Park, E. and Smucker, A. J. M. (2005). Saturated hydraulic conductivity and porosity within macroaggregates modified by tillage. Soil Science Society of American Journal (69), DOI: 10.2136/sssaj2005.0038

Renard, K. G., Foster, G. R., Weesies, G. A., McCool, D. K. and Yoder, D. C. (1997). Predicting soil erosion by water: a guide to conservation planning with the Revised Universal Soil Loss Equation (RUSLE). Washington: USDA Agriculture Handbook, 703, p387- 889.

Saxton, K. W. and Rawls, W. J., Romberger, J. S. and Papendick (1986). Estimating generalized Soil-water characteristics from Texture. https://doi.org/10.2136/sssaj1986.03615995005000040039x

Soil Survey Staff. (1999). Soil Taxonomy Manual. A basic system of soil classification for making and interpreting soil surveys, $2^{\text {nd }}$ edition. Agriculture Handbook 436, Natural Resources Conservation Service, USDA, Washington DC, USA, http//doi.org/10.1111/j.1475-2743. 2001.tb00008.x

Stutter, M. I., Decks, I. K. and Billet, M. F. (2004). Spatial variability in soil ion exchange chemistry in a granitic upland catchment. Soil Science Society of America Journal, (68), https://doi.org/ 10.2136/sssaj2004.1304

Udo, E. J., Ibia, T.O., Ogunwale, J. A., Ano, A.O. and Esu, I. E. (2009). Manual of soil, plant and water analysis. Sibon books limited Lagos Nigeria.183 pp

Vanelslande A., Rousseau, P., Lal, R., Gabriels, D. and Ghuman, B. S. (1984). Testing the applicability of a soil erodibility nomograph: In: Challenges in African Hydrology and Water Resources. Proceeding of Harare Symposium. July, 1984. International Association of Hydrological Sciences Publication. 144, 463-473 pp

Wischmeier, W. H. and Smith, D. D. (1978). "Predicting Rainfall Erosion Losses. A guide to conservation planning". Agriculture Handbook No. 537. USDA/Govt. Printing Office, Washington, DC. 58 pp

Wischmeier, W.H., Johnson, C. B. and Cross, B. V. (1971). "A soil erodibility nomograph for farmland and construction sites." Journal of Soil and Water Conservation 26:189-193. ISSN 1941-3300 